DOI: http://dx.doi.org/10.22484/2177-5788.2016v42n1p165-174

\title{
Tradução, adaptação, refração: considerações sobre uma adaptação de Pride and Prejudice
}

\author{
Isabela Sabbatini
}

Resumo: O artigo apresenta considerações sobre a relação entre Estudos da Tradução e Estudos de Adaptação, fazendo uso do exemplo do vlog The Lizzie Bennet Diaries como adaptação do romance Pride and Prejudice, da escritora inglesa Jane Austen. O conceito de refração, como elucidado por Lefevere (1982/1992) é proposto como elo conciliador das duas vertentes de estudo.

Palavras-chave: Refração. Adaptação. Tradução. Austen.

Translation, adaptation, refraction: considerations about an adaptation of Pride and Prejudice

Abstract: The article raises questions about the relationship between Translation Studies and Adaptation Studies, using the example of the vlog The Lizzie Bennet Diaries as an adaptation of the novel Pride and Prejudice, by the English writer Jane Austen. The concept of refraction, as elucidated by Lefevere $(1982 / 1992)$ is proposed as a conciliator link between the two areas of study.

Keywords: Refraction. Adaptation. Translation. Austen. 


\title{
Introdução
}

A máxima de que "O original é sempre melhor" é corrente não apenas quando se fala em traduções, mas também quando se trata de adaptações. Hutcheon (2006, p.2) nota que "in both academic criticism and journalistic reviewing, contemporary popular adaptations are most often put down as secondary, derivative", e, portanto, não dignas de serem estudadas. Entendo adaptação aqui conforme a definição de Sanders (2006, p. 18-19), em termos do que ela pode ser:

\begin{abstract}
Adaptation can be a transpositional practice, casting a specific genre into another generic mode, an act of re-vision in itself. It can parallel editorial practice in some respects, indulging in the exercise of trimming and pruning; yet it can also be an amplificatory procedure engaged in addition, expansion, accretion, and interpolation [...]. Adaptation is frequently involved in offering commentary on a sourcetext. This is achieved most often by offering a revised point of view from the 'original', adding hypothetical motivation, or voicing the silenced and marginalized. Yet adaptation can also constitute a simpler attempt to make texts 'relevant' or easily comprehensible to new audiences and readerships via the processes of proximation and updating.
\end{abstract}

Alguma relação entre os Estudos da Tradução e os de Adaptação sempre esteve presente, apesar de raramente ser explorada. Hutcheon (2006, p. 16) comenta brevemente a natureza intersemiótica de adaptações, concluindo que sim, adaptações são um tipo particular de tradução:

\footnotetext{
In many cases, because adaptations are to a different medium, they are re-mediations, that is, specifically translations in the form of intersemiotic transpositions from one sign system (for example, words) to another (for example, images). This is translation but in a very specific sense: as transmutation or transcoding, that is, as necessarily a recoding into a new set of conventions as well as signs.
}

Cahir (2006), por outro lado, rejeita o termo adaptação, em favor do termo tradução, mas não cita nenhuma teoria da área de Tradução de modo a fundamentar sua visão. De maneira simplista, define o termo tradução como "to move a text from one language to another" (p. 7), enquanto adaptar "means to alter the structure or the function of an entity so that it is better fitted to survive and multiply in its new environment" (p. 7). Cahir incorre no erro de acreditar que, já que a Biologia faz uso do mesmo termo para dar conta de um processo natural, o mesmo 


\title{
SABBATINI, Isabela. Tradução, adaptação, refração.
}

seria válido para um sistema artificial como a literatura ou o cinema. Lefevere (1992, p. 12) escreve que:

\begin{abstract}
Literature - a literature - can be analyzed in systemic terms. Systems thinking would call it a "contrived" system, because it consists of both texts (objects) and human agentes who read, write, and rewrite texts. [...] The fact that literature is a contrived system should caution us against any attempt to force it into an analogy with physical or biological systems, which are amenable to a more rigid description.
\end{abstract}

Adaptação na literatura, no cinema, nas mídias de maneira geral, não é um processo natural, e, portanto, não segue as mesmas regras rígidas. Esta envolve um aspecto de transcodificação ou transmutação, mas as mesmas regras que se aplicam ao estudo de traduções também se aplicam ao estudo de adaptações?

\section{Tradução $=($ Refração $=)$ Adaptação(?)}

Lefevere (1982, p. 235) introduz o conceito de refração ${ }^{1}$ como "the adaptation of a work of literature to a different audience, with the intention of influencing the way in which that audience reads the work", e inclui como exemplos de refração os mais variados textos, como traduções, críticas, antologias etc., que tenham sido "extremely influencial in establishing the reputation of a writer and his or her work". Refrações, além disso, estão presentes em grande escala em nossa cultura, de modo que "writers and their work are always understood and conceived against a certain background, or, if you will, are refracted through a certain spectrum" (LEFEVERE, 1982, p. 234).

Quanto à relação entre tradução (reconhecidamente um exemplo de refração) e adaptação, Lefevere (1992, p. 9, com grifo meu) defende que os mesmos processos regem ambos: "The same basic process of rewriting is at work in translation, historiography, anthologization, criticism, and editing. It is obviously also at work in other forms of rewriting, such as adaptations for film and television...".

\footnotetext{
${ }^{1}$ Em seu livro de 1992, Translation, Rewriting \& the Manipulation of Literary Fame, Lefevere prefere o termo "rewriting", reescrita, ao invés de refração. Levando em conta o elemento visual didático que o termo "refração" evoca, preferi utilizá-lo ao longo do artigo em detrimento de "reescrita".
} 
Nota-se que Lefevere ainda faz distinção entre tradução, um processo linguístico, e adaptação, um processo de transcodificação. Assim, mesmo reconhecendo que são ambos constituem exemplos de refração, opto por continuar a me referir aos dois processos diversos com nomenclaturas diversas.

Tanto tradutores quanto adaptadores "manipulate the originals they work with to some extent, usually to make them fit in with the dominant ideological and poetological currents of their time" (LEFEVERE, 1992, p. 8). No caso de adaptações, tal manipulação fica mais aparente no caso de adaptações que não visam reprodução de seu texto fonte, ou, como coloca Sanders (2006), fazem uso criativo da infidelidade ${ }^{2}$, como se observa na mais recente adaptação do romance mais conhecido de Jane Austen para o meio digital.

\section{Uma refração de Austen: o caso de The Lizzie Bennet Diaries (2012-2013)}

Com 203 anos de publicação, Pride and Prejudice ${ }^{3}$ (Orgulho e Preconceito) talvez nunca tenha sido tão popular. Cartmell (2010, p. 8-10) identifica cinco filmes para o cinema e sete adaptações para a televisão entre os anos de 1938 e 2007, uma recorrência que caracteriza o que Azerêdo (2013, p. 15) chama de Austenmania. Não obstante, Austen permanece uma autora canônica tanto dentro quanto fora da universidade. Cartmell (2010, p. 14) observa que "Austen is second only to Shakespeare as a canonical author" -, uma relação que pode ser explicada pelo mesmo argumento de Lefevere (1992, p. 20) acerca da publicação em massa de livros considerados clássicos: "classics taught will be the classics that remain in print, and therefore the classics that remain in print will be the classics known to the majority of people exposed to education in most contemporary societies."

A corrente de adaptações chegou, em 2012, ao mundo virtual com o vlog The Lizzie Bennet Diaries (2016). Trata-se de uma série que conta com mais de 100 curtos vídeos publicados no YouTube, que acompanham cerca de um ano na vida de Lizzie Bennet, agora não mais uma jovem inglesa vivendo no campo no século XIX, mas uma estudante americana do

\footnotetext{
2 "It is usually at the very point of infidelity that the most creative acts of adaptation and appropriation take place."

${ }^{3}$ A edição usada como base para este artigo é a da Harvard University Press de 2010, referenciada a baixo.
} 
século XXI que nos conta sobre seu dia a dia. O conceito de vlog é dado por Lange (SNICKARS; VONDERAU, 2010, p. 86) como:

A video blog or vlog is similar to a blog, in that videos are posted in reverse chronological order so that the viewer encounters the most recent video first. Although video blogs may contain text graphics and photographs, video bloggers often prefer to privilege video as the central mode of communication.

Conversando diretamente com a câmera - e assim fazendo da Internet sua interlocutora - Lizzie narra duas desventuras para pagar dívidas estudantis, os meandros da vida amorosa de sua irmã mais velha, Jane; impaciência com a energética irmã mais nova, Lydia; sempre tendo como foco principal o progresso profissional das três irmãs Bennet. A preocupação econômica é sentida por todo o vlog, costumeiramente mesclado ao humor associado à fixação de Mrs. Bennet em casar as filhas. No $19 .^{\circ}$ episódio ${ }^{4}$, Lizzie resume a relação entre estes dois fatores na seguinte - e, para ela, assombrosa - frase: "Is this whole marriage fixation a race to get us out of the house before there isn't a house to get us out of anymore?". (Fitz)William Darcy é na adaptação, não mais um gentleman de origens aristocráticas, mas CEO de uma companhia online nos moldes da Google, Pemberley Digital (2016) - domínio hoje dos produtores da web série.

Pode-se afirmar que o vlog busca fidelidade junto ao original na medida em que as preocupações econômicas são reais, sempre presentes, e nunca concretizadas - assim como Mr. Bennet não vem a falecer e deixar suas filhas destituídas em Pride and Prejudice, em The Lizzie Bennet Diaries os pais de Lizzie conseguem eventualmente pagar a hipoteca da casa. Atenção à ideia de fidelidade é uma discussão cara tanto aos Estudos de Adaptação quanto aos Estudos de Tradução. "The question", como coloca Cahir (2006, p. 9) ao comentar os preconceitos enfrentados por adaptadores e tradutores, “is not that of the translator's faithfulness, but of its faithfulness to what?" Seguindo um modelo semelhante ao de D'hulst (2001) para o estudo historiográfico de traduções, Lefevere (1992, p. 7) defende que "Those engaged in that study [of rewritings] will have to ask themselves who rewrites, why, under what circumstances, for

\footnotetext{
4 “The Green Bean Gelatin Plan - Ep 19”. Disponível em 〈https://www.youtube.com/watch?v=ce_URjhJ3Xs〉. Acesso em 30 mar. 2016.
} 
which audience." Hutcheon (2006, p. 7), por fim, resume a discussão acerca de fidelidade ao observer que "the morally loaded discourse of fidelity is based on the implied assumption that adapters aim simply to reproduce the adapted text [...]. Adaptation is repetition, but repetition without replication."

O objetivo de uma adaptação, portanto, não se encontra em tentar reproduzir o original, mas em transcodificar elementos - a história, o estilo do autor etc. - para uma nova mídia. No entanto, pensando nas adaptações do romance anteriores a 2002 para a televisão, todas period pieces, Cardwell (2002, p. 134) observa que "Austen adaptations had by the 1990s become representative of the genre of classic-novel adaptations as a whole and have played a vital role in consolidating the traits which adaptations share (and which make them all look the same)."

O sentimento de mesmice está atrelado à noção de fidelidade ao original, que por sua vez leva as adaptações a adotarem traços semelhantes e criarem a impressão superficial de que se está sempre reinventando a roda. Contudo, de volta a afirmação de Lefevere (1992) de que toda refração implica uma tomada de posição ideológica por parte dos adaptadores, faz-se necessário um olhar mais cauteloso para com tantas repetições. Quais seriam as diferentes ideologias que as regem, e como elas se relacionam com a ideologia em vigência na época em que o romance foi escrito?

\section{Ideologia e adaptação em $L B D$}

Kaplan (1992), em Jane Austen (2010) Among Women, faz um estudo historiográfico das cartas, diários, poemas e outros materiais escritos produzidos pela família de Austen e por seus vizinhos e correspondentes. Seu estudo se baseia na ideia de polissistema de cultura, semelhante ao método sistêmico adotado por Lefevere (1992). Kaplan (1992, p. 4) defende que Austen vivia uma dualidade cultural, já que ela e suas amigas:

[...] subscribed to the larger, mixed community's patriarchal concept of the female, organised by the ideology of domesticity. They also produced among themselves an alternative vision of an independent, self-assertive female, implicitly and explicitly critical of the dominant patriarchal version of the female self and her domestic duties. 
Kirkham (1983, p. 3) chega a afirmar que a obra de Austen "deserves to be called feminist since it was concerned with establishing the moral equality of men and women and the proper status of individual women as accountable beings." Kaplan (1992), no entanto, afirma que, por viver nessa situação de dualidade cultural, Austen não só participava da ideologia patriarcal do gentry, mas de maneira conciliatória também era parte de uma cultura das mulheres de seu tempo. Nas suas palavras:

\footnotetext{
Women's culture [which] criticized the ideology of domesticity by reversing its value structure, by putting women and their experiences and desires first. Nevertheless, such criticism did not challenge the gentry's patriarchal culture. Rather, it enabled accommodation. (KAPLAN, 1992, p. 78).
}

De maneira mais significativa, é a linguagem dessa cultura das mulheres que Austen coloca na voz de Elizabeth Bennet em Pride and Prejudice. Kaplan (1992, p. 191) argumenta que é tentador identificar Elizabeth Bennet com Jane Austen, mas que apenas conhecemos Austen textualmente e através de testemunhos de seus familiares. Portanto, Elizabeth apenas soa como Austen em suas cartas para amigas e parentas mulheres, por meio das cartas nas quais exercita a linguagem característica da cultura das mulheres.

Quanto à ideologia que rege a adaptação mais recente, Bernie Su (2014, entrevista complementar inserida ao final do livro), um dos principais responsáveis pela realização de The Lizzie Bennet Diaries, explica que a intenção dos adaptadores, desde o início, era a de frisar o aspecto econômico:

\footnotetext{
We wanted to modernize the independent woman. Back in the $1800 \mathrm{~s}$, there weren't a lot of options in careers, and it was important to us that career choices be an underlying current to every major decision our characters make. We didn't want it to be about finding the right guy/marrying a rich guy.
}

Dado o próprio formato do vlog - uma personagem falando diretamente com a câmera - e o gênero confessional do diário assumido no próprio título, o vlog configura um espaço no qual Lizzie expõe suas experiências, frustrações e desejos através de um meio bastante íntimo, fazendo um paralelo interessante com o conceito proposto por Kaplan (1992) da cultura das mulheres. Estes sentimentos e opiniões contrastam com as expectativas de sua mãe, que pode 
representar as vontades mais conservadoras da sociedade que veem em uma mulher solteira uma pessoa incompleta, sem levar em conta sua carreira. Lizzie também entra em conflito com exigências econômicas, como a recusa de um emprego de alta remuneração que implicaria na sua desistência dos estudos ${ }^{5}$ - no romance, o paralelo é com a recusa do pedido de casamento de Mr. Collins, que virá a herdar a propriedade do pai de Elizabeth.

Em sua conversa com a Internet, Lizzie cria um espaço de diálogo das mulheres que, contrastado ao período em que escrevia Austen, deixa de ser restrito apenas a mulheres ou a drawing rooms. Suas experiências passam a ser compartilhadas por um grande número de viewers, de modo a criar um espaço de fato feminista para seu público não especializado no estudo de literatura (ou leitores não profissionais, como os caracteriza Lefevere (1992). O vlog coloca o público em contato com a obra de Austen em larga escala, contribuindo para maior popularização do romance, como escreve Hank Green (2013, p. 9), ao comentar a escolha do livro de Austen para seu experimento de contar uma história usando o vlog como plataforma: "That was our intent... to benefit from the success of this great work, but also to increase it."

\section{Conclusão}

Green (2013, p. 9, grifo meu) também comenta que "Pride and Prejudice is a work, like many these days, that is known more through its adaptations than in it's [sic] original form." Hutcheon (2006, p. 4) também chama atenção para a "onipresença" de adaptações em nossa cultura, e esta é a justificativa levantada por Lefevere (1992, p. 7) para o estudo de refrações:

Since non-professional readers of literature are, at present, exposed to literature more often by means of rewritings than by means of writings, and since rewritings can be shown to have had a not negligible impact on the evolution of literatures in the past, the study of rewritings should no longer be neglected.

\footnotetext{
5 “The Insistent Proposal - Ep. 39" Disponível em <https://www.youtube.com/watch?v=WmZzaAsPHNo\&list=PL6690D980D8A65D08\&index=39> Acesso em 30 mar. 2016.
} 
The Lizzie Bennet Diaries apresenta-se como uma adaptação inovadora por seu meio o prisma através do qual Pride and Prejudice é refratado, o YouTube -, sendo a primeira web série de inspiração literária em uma longa lista: pelos mesmos produtores de $L B D$ (PEMBERLEY digital, 2016) seguiram-se Welcome to Sanditon (baseada no manuscrito inacabado de Austen, Sanditon), Emma Approved (adaptação do romance Emma, também de Austen), Frankenstein M.D. e The March Family Letters (adaptação de Little Women, de Alcott), e outro sem número de web séries literárias dispersas pelo YouTube. Refrações de literatura na Internet tendem apenas a se multiplicar e seu impacto na cultura leitora ainda não está claro. Como defende Lefevere, o estudo destas adaptações não deve ser negligenciado.

\section{Referências}

AUSTEN, Jane. Pride and prejudice: an annotated edition. Introdução e notas de Patricia Meyer Spacks. Cambridge: Harvard University Press, 2010.

AZERÊDO, Genilda. Para celebrar Jane Austen: diálogos entre literatura e cinema. Curitiba: Appris, 2013.

CAHIR, L. C. Literature into film: theory and practical approaches. Jefferson: McFarland \& Company, 2006.

CARDWELL, Sarah. Adaptation revisited: television and the classic novel. Manchester: Manchester University Press, 2002.

CARTMELL, Deborah. Screen adaptations: Jane Austen's Pride and Prejudice. London: Methuen Drama, 2010.

D'HULST, L. Why and how to write Translation Histories. In: MILTON, J. (Org.) Emmerging views on translation history in Brazil. CROP (special edition), 2001. v. 6.

GREEN, Hank. Foreword. In: AUSTEN, Jane. Pride and prejudice: the Lizzie Bennet Diaries Edition. Pemberley Digital in association with DFTBA Records, 2013.

HUTCHEON, L. A theory of adaptation. New York: Routledge, 2006.

KAPLAN, Deborah. Jane Austen among women. Baltimore: The Johns Hopkins University Press, 1992.

KIRKHAM, Margaret. Jane Austen, feminism and fiction. Brighton: The Harvester Press, 1983. 
LEFEVERE, Mother. Courage's cucumbers: text, system and refraction in a theory of literature. 1982. In: VENUTI, L. The translation studies reader. London: Routledge, 2004.

LEFEVERE, Mother. Translation, rewriting \& the manipulation of literary fame. London: Routledge, 1992.

LIZZIE BENNET. (2012-2014). The Lizzie Bennet Diaries [canal de vídeos online]. Disponível em <https://www.youtube.com/user/LizzieBennet>. Acesso em: 30 mar. 2016

PEMBERLEY Digital. Disponível em < http://www.pemberleydigital.com>. Acesso em 30 mar. 2016.

SANDERS, J. Adaptation and appropriation. London: Routledge, 2006.

SNICKARS, Pelle; VONDERAU, Patrick (Eds.). The YouTube Reader. National Library of Sweden, 2010.

SU, Bernie; RORICK, Kate. The Secret Diary of Lizzie Bennet. New York: Touchstone, 2014.

Isabela Sabbatini - Universidade de São Paulo - USP | São Paulo | São Paulo. Contato: isafs90@gmail.com 